\title{
Customary Law, Social Development and Administration of Justice in Nigeria
}

\author{
Matthew Enya Nwocha \\ Faculty of Law, Ebonyi State University, Abakaliki, Nigeria \\ Email: nwochaenyaeni@gmail.com
}

How to cite this paper: Nwocha, M. E. (2016). Customary Law, Social Development and Administration of Justice in Nigeria. Beijing Law Review, 7, 430-442. http://dx.doi.org/10.4236/blr.2016.74034

Received: November 25, 2016

Accepted: December 27, 2016

Published: December 30, 2016

Copyright (@) 2016 by author and Scientific Research Publishing Inc. This work is licensed under the Creative Commons Attribution International License (CC BY 4.0).

http://creativecommons.org/licenses/by/4.0/

(c) (i) Open Access

\begin{abstract}
Customary law is the law that captures the norms, traditions and rules of behaviour of the people. It is the law propelled by the worldview, beliefs, philosophies and value system of the people. In traditional societies, customary laws were largely unchallenged save by compelling innovations that re-channeled aspects of the practices of the people and subsequently altered its traditions. Since the introduction of English law in the administration of justice in Nigeria about a century ago, customary law has been fighting for breath and a large chunk of it has not survived the conflict that was the necessary outcome of the contact. This paper has discussed the nature of justice that the hybrid legal system has produced. It has answered the question whether the judicial system that yields legal justice has produced social justice as well. It has also made projections into the future of customary law and examined the imperatives of a smoother marriage of convenience between the borrowed English legal system and native law and custom so as to achieve justice that is real and answers to the needs of the society. The topic is discussed under six sub-heads, namely: Introduction; conceptual analysis; application of customary law in Nigeria; customary law and justice; customary law and arbitration; and conclusion. Under conceptual analysis, the meaning, sources and progressive development of customary law have been examined including their relationship with the English common law. On the application of customary law, the standard requirements for the validity and enforcement of the law have been discussed critically. The capacity of customary law to produce both legal and social justice has been evaluated under the sub-head of customary law and justice while the content, context and legal status of customary arbitration and customary awards have been treated under customary law and arbitration. The co-relation between customary law and social development was examined and practical policy formulations suggested for enhancing the role of customary law in social development. The conclusion summarized salient points raised and evaluated in the work and projected the capacity of customary law to play a more pro-active role in the administration of justice in Nigeria when and after obvious negative tendencies
\end{abstract}


by the operators have been eliminated or at least minimized.

\section{Keywords}

Customary Law, Common Law, English Legal System, Osu Caste System, Customary Arbitration, Native Law and Custom

\section{Introduction}

The basic reason for this paper is to highlight the potentials for customary law to contribute to both legal and social justice in a way that eliminates the bottlenecks that have bogged down the current legal and judicial system which Nigeria has borrowed from Britain as a result of her colonial history and relation with the then British empire. The apparent complications inherent in this received legal system lies in the fact that Nigeria is a highly heterogeneous society with well above a hindered ethnic groups each with their own cultures, languages and customary laws. Given this scenario and with a high level of illiteracy among the general population, an attempt to foist the received English legal system on the nation has been problematic. The English legal system, particularly the official judiciary, is viewed by a great majority of the people as an elitist institution. Because of the many problems of the English legal system such as prolonged delay in adjudication of disputes, high cost of litigation, corruption and the bitterness and rancour that follow court judgments, a large chunk of the population feel alienated from this foreign and in most cases, strange legal system. They would rather resort to their more familiar customary laws to settle disputes and determine regular issues such as marriage and inheritance rights. Since these customary laws belong to the people, they are more able to understand the system and to accept a settlement or determination that emanates from it. This way, legal justice coincides with social justice and society is put on a surer path of progress. This paper is therefore intended to make a case for the blending of customary law with the received English law in such a way that the people do not only have the opportunity of legal justice but can obtain social justice as well leading overall to a progressive social development in the country.

\section{Conceptual Analysis}

The Black's Law Dictionary defines custom as a practice that by its common adoption and long, unvarying habit has come to have the force of law. It also defines customary law as law consisting of customs that are accepted as legal requirements or obligatory rules of conduct, practices and beliefs that are so vital and intrinsic a part of a social and economic system that they are treated as if they were laws (Garner, 2009: p. 443). According to Kolajo (2001):

Customary law can also be described as a usage or practice of the people which by common adoption and acquiescence and by lone and unvarying habit has become compulsory and has acquired the force of a law with respect to the place or the 
subject-matter to which it relates. (Kolajo, 2001)

The Nigerian Evidence Act did not define customary law but it did define custom as a rule, which in a particular district, has, from long usage, obtained the force of law ${ }^{1}$. In Olubodun v. Lawa?, the Supreme Court of Nigeria defined custom or customary law to mean a set of rules of conduct applying to persons and things in a particular locality. It went further to state that it is of the characteristics of a custom or customary law that it must be recognized and adhered to by the inhabitants of the community to make it binding. To emphasis the unwritten content of customary law, the Court stated that it is a well established principle of law that documentary evidence is unknown to native law and custom. In Owoniyin v. Omotosho ${ }^{3}$, the Court described customary law as a mirror of accepted usage. Whereas we agree with the above definitions in various degrees, we think that the one offered by the Supreme Court in Nwaigwe v. Okere ${ }^{4}$, is more comprehensive and commands wider acceptance. It proceeds:

What is customary law? Customary law generally means relating to custom or usage of a given community. Customary law emerges from the traditional usage and practice of a people in a given community which by common adoption and acquiescence on their part, and by long and unvarying habit, has acquired, to some extent, element of compulsion, and force of law with reference to the community. And because of the element of compulsion which it has acquired over the years by constant, consistent and community usage, it attracts sanctions of different kinds and is enforceable. Putting it in a more simplistic form, the customs, rules, relations, ethos and cultures which govern the relationship of members of a community are generally regarded as customary law of the people $e^{5}$

The argument whether traditional African societies possessed laws no longer arises in contemporary times in the light of the volume of literature and case law that has developed on the subject, for as Umoh (2000) summarized any rule that resolves conflict and stabilizes society is law, however crude ${ }^{6}$.

The next issue to resolve is the relationship between customary law in traditional African societies and the common law of England. It is necessary to clarify this point here because in the colonial era African customary law was generally regarded by the euro-centric colonial operators as barbaric, inordinate and inapplicable save those ones that have passed the repugnancy tests set by them whereas several aspects of the com${ }^{1}$ Section 258 (1) Evidence Act, 2011. The definition was restated in Okafor vs. Okafor (2005) 2 SMC 416 ratio 5. Section 2 of the Ebonyi State Customary Court Law CAP. 47 Laws of Ebonyi State, 2009, defines customary law as a rule or body of customary rules regulating rights and imposing correlative duties being customary rules which obtain and are fortified by established usage and which are appropriate and applicable to any particular cause, matter, dispute, issue or question.

${ }^{2}$ (2009) 35 NSCQR 570.

${ }^{3}(1961)$ All NLR 304. The Supreme Court also adopted the definition in Zaiden vs. Mohssen (1973) 11 SC 1 and Kindley vs. Military Governor of Gongola State (1988) 2 NWLR (Pt 77) 445.

${ }^{4}(2008) 34$ NSCOR 1325.

${ }^{5}$ Per Niki Tobi J.S.C.

${ }^{6}$ P. U. Umoh. "Law in African Context", cited in M. E. Nwocha (2013). Human Rights and Criminal Justice in Nigeria.Abakaliki, CE DarrollsPublishers. 
mon law of England were transported to apply directly to the colonial territories as statutes of general application without let or hindrance. If the common laws of England were nothing more than the customary laws and principles of morality of the English people then the supercilious condescension on African customary laws would have been unjustified. According to Black's Law Dictionary, common law is the body of law derived from judicial decisions, rather than from statutes or constitutions ${ }^{7}$. Throwing more light on this in a description of the England customary law, Devlin (2009) wrote that:

Historically, (the common law) is made quite differently from the continental code. The code precedes judgments; the common law follows them. The code articulates in chapters, sections and paragraphs the rules in accordance with which judgments are given. The common law on the other hand is inarticulate until it is expressed in a judgment. Where the code governs, it is the judges' duty to ascertain the law from the words which the code uses. Where the common law governs, the judge, in what is now the forgotten past, decided the case in accordance with morality and custom and later judges followed his decision. They did not do so by construing the words of his judgment. They looked for the reason which had made him decide the case the way he did, the ratio decidendi as it came to be called. Thus, it was the principle of the case, not the words which went into the common law. So historically the common law is much less fettering than a code ${ }^{8}$.

From the foregoing analysis, it is clear that both the common laws of England and African customary law enjoy the same origin and history and none is superior to the other. This position finds support in Nwaigwe v Okere ${ }^{9}$, where Onnoghen who read the lead judgment emphasized that we should not forget that English law also includes English common law which does not enjoy a higher legal status than our customary law $w^{10}$.

Legal justice is a much more restrictive term than social justice for social justice encompasses in general terms the capacity of the political and legal system to secure and guarantee to each and to all, deserving, fair and equal treatment in the scheme of things within a given society. Social justice ensures in an entity that minority rights are protected; that women, children and the vulnerable are cared for, protected and fairly treated; that the economic system does not only benefit the few while the majority languish in penury; that economic equilibrium is as much as possible sustained; that citizens have equal and unhindered access to governance by equal access to franchise and participation; that citizens are equal beneficiaries of government patronage and of the nation's natural endowments; and that the laws of the land are made and the Courts

\section{${ }^{7}$ (Supra) p. 313}

${ }^{8} \mathrm{P}$. Devlin cited in Black's Law Dictionary, Op.cit. p. 313. It is noted here that aside of the Statutes of General Application, English case law which had built up as judicial precedent had direct application in Nigeria before independence and became persuasive authority in Nigerian Courts after independence till date.

${ }^{9}$ (Supra) at p. 1357.

${ }^{10}$ Walter S.N. Onnoghen J.S.C. 
poised respectively to offer these distributive and corrective justices. In contradistinction to social justice, legal justice is justice according to law. Whereas social justice answers to moral questions, legal justice answers only to the hard cold letters of the law. Legal justice is an outgrowth in a large measure of what legal scholars describe as the positive law sharing common features with modern realism of which Holmes described as the prophecies of what the Courts will do in fact and nothing more pretentious and subsequently presented as the embodiment of the fears of a bad man who suspected what the Courts would do to him (Holmes, 2013).

In many respects, legal justice does not correspond to social justice. Take as instance Sections $14-18$ of the 1999 Constitution which confers various social, economic, and educational entitlements on the citizens. Social justice demanded that the citizens seized of these rights should be able to consummate the rights by calling in aid the apparatus for the administration of justice. But this is not the case for section 6(6)(C) of the same Constitution states unequivocally that the judicial powers vested on the Courts by the Constitution shall not extend to any issue or question as to whether any act or omission by any authority or person or as to whether any law or any judicial decision is in conformity with the fundamental objectives and directive principles of state policy set out in Chapter II of the Constitution. This blanket ban, of course, includes Sections 14 - 18 earlier mentioned. By this development, the window of opportunity for the citizens to obtain a wide range of social justice by accessing vital economic and educational opportunities and facilities has been shut behind their face.

Conversely, Sections 33 - 46 of the same Constitution make provisions for several classes of civil and political rights. Unlike the previous scenario, section 46(1) authorizes any person who alleges that any of the rights he is entitled to under the sections has been, is being, or is likely to be contravened to apply to the appropriate High Court to seek redress. The High Courts are further empowered under Section 46(2) to hear and determine any such application made to it and to make any orders, issue such writs and give such directions as it may consider appropriate for the purpose of enforcing or securing the enforcement of any right to which the applicant may be entitled. To practicalize the exercise of these rights Section 46(3) empowers the Chief Justice of Nigeria to make rules with respect to the practice and procedure of the relevant Court for the purpose of enforcing the rights. These civil guarantees are good but in practice, not many people are in a position to access the rights due to a multiple of reasons. Foremost of these reasons is the large economic divide existing between the Country's few rich and its vast army of the poor. With overwhelming majority of the citizens living below poverty line only a minute percentage of the population can go through the back-breaking processes of enforcing their rights. Most people prefer not to raise formal complaint while others resign to fate. Yet a significant obstacle aside of poverty is ignorance. The illiterate population in Nigeria is still predominant. Illiteracy is concomitant with ignorance. With these people working all day as subsistence farmers, artisans, small-scale traders and unskilled labourers struggling to keep body and soul together questions of human rights and their enforcement seem to be out of reach. The 
corrupt, brutal and over-bearing attitudes of the security forces are also unhelpful. Most times the police constitute themselves into a pest eating away at an undernourished human population. To ameliorate this, and pave the way for progressive social development, the government, both at the Federal and State, has in fairness put in place some programmes aimed at bridging the gap between the rich and the poor and reducing the level of social inequality. These are poverty alleviation programmes, soft loans for agricultural production and for small-scale businesses and entrepreneurs aside of subsidies in energy, education and transportation services. There has also been a deliberate effort to provide legal aid services to the indigent. Section 46(4) (b) (i) of the 1999 Constitution mandates the National Assembly to make legislations for the rendering of financial assistance to indigent citizens of Nigeria where there rights have been infringed or with a view to enabling them to engage the services of a legal practitioner to prosecute their claims. Section 7 of the Legal Aid Act ${ }^{11}$ makes provision for the offering of legal assistance to indigent persons in both civil and criminal matters. With regard to civil matters, such assistance will only relate to civil claims in accident cases and cases of breach of fundamental rights as guaranteed under Chapter IV of the 1999 Constitution. In criminal matters, among the cases covered are allegations of murder, manslaughter, grievous bodily harm, affray, stealing and rape as well as aiding and abetting or counseling or procuring the commission of, or being an accessory before or after the fact to, or attempting or conspiring to commit any of the above offences. In spite of these legislative provisions, a number of problems still trail the scheme in practice significant among which is funding. The scheme is poorly funded by the government to the end that there are not only scanty services to be accessed by those who need them but even those who succeed in accessing them find that most of the lawyers who operate the scheme are either inexperienced or are not motivated to give their quality time and services to the programme. Furthermore, sometimes the assistance is not available to those who really need them whereas those who do not need them take advantage of the programme due to false claims and official corruption. Apart from these, the legal aid scheme in Nigeria is by far not a comprehensive one for it covers only two areas of civil claim and a scanty number of allegations. A predominant percentage of all the things that can bring an indigent person before the Court to be able to obtain legal justice are untouched. And considering the overwhelming percentage of the poor as against the rich in the Country today a conclusion may be drawn that only an infinitesimal size of the population are able to obtain legal justice and this impinges highly on the balancing of social justice in the Country. The following discourse focuses on the practical application of customary law in Nigeria.

\section{Application of Customary Law in Nigeria}

Nigeria is made up of 36 states with a federal capital territory in Abuja. Nigeria is further divided into six geopolitical zones, namely, the Northeast, Northwest, North Central, Southwest, Southeast, and South-South. Each of the zones is made of six seats ex${ }^{11}$ LFN 2004. 
cept the Northwest and the Southeast that has seven and five states respectively (Trost, 2005). The country is also a heterogeneous society with a multiplicity of cultures, religions, languages and customary laws. The northern part of the country is dominated by the Hausa, Fulani and other ethnic groups that practice Islamic religion and Sharia law (Ibrahim, 2012) ${ }^{12}$. According to Obilade (1979):

In Nigeria, customary law may be divided in terms of nature into two classes, namely, ethnic or non-Moslem customary law and Moslem law. Ethnic customary law in Nigeria is indigenous. Each system of such customary law applies to members of a particular ethnic group. Moslem law is religious law based on the Moslem faith and applicable to members of the faith. In Nigeria, it is not indigenous law; it is received customary law introduced into the county as part of Islam ${ }^{13}$.

The Southern States or zones of the country are predominantly non-Moslem with indigenous customary laws ${ }^{14}$. As Kolajo (2001) has observed, in some cases, statute, common law and customary law co-exist and are applicable (Kolajo, 2001). However, whereas customary law is observed routinely by the people who own them in their daily lives, it has only limited application in Nigerian Courts. Section 16 of the Evidence Act gives two conditions in which any custom may be adopted as part of the law governing a particular set of circumstances, that is, if it can be judicially noticed or can be proved to exist by evidence. And the burden of proving a custom lies on the person alleging its existence. Section 17 of the Evidence Act explains that a custom may be judicially noticed when it has been adjudicated upon once by a superior court of record.

In Adekeye v. Adesina ${ }^{15}$ the facts were that on the $23^{\text {rd }}$ day of August 1996, the Oloyan of Oyan died and a new Oloyan had to be crowned. The Oloyan Chieftaincy had four Ruling Houses and the Oloyan must be chosen from one of them. The kingmakers decided that it was the turn of Elemo Ruling House to produce an Oloyan. There was no protest from the other three Ruling Houses. The $1^{\text {st }}$ Appellant was from the Aresinkeye lineage. He was eventually appointed and installed as the Oloyan of Oyan in 1979. This appointment did not go down well with the Respondent who was from the Olorinoye Lineage and he challenged the appointment in Court. His case was that the Elemo Ruling House had in the past produced three Oloyans with one coming from Oloarinoye and two in succession from Aresinkeye. The learned trial judge agreed with the $1^{\text {st }}$ respondent and found that is was indeed the turn of Oloarinoye to produce the Oloyan and not the Aresinkeye Lineage. This judgment was affirmed by the Court of Appeal and further appealed to the Supreme Court. In allowing the appeal, the Supreme Court held among other things that where a Declaration in respect of a recog-

${ }^{12}$ H. Ibrahim (2012). Practicing Sharia Law. Illinois, ABA Publishing; States in the northern zones implementing Sharia law are Bauchi, Borno, Gombe, Jigawa, Kaduna, Kano, Katsina, Kebbi, Niger, Sokoto, Yobe and Zamfara.

${ }^{13}$ A. O. Obilade (1979). The Nigerian Legal System. Ibadan, Spectrum Books Ltd; Section 2 of the High Court Law Cap. 49 Laws of Northern Nigeria, 1963, provides that native law and custom includes Moslem Law.

${ }^{14}$ States in the South where this obtains include Ebonyi, Abia, Imo, Enugu, Anambra, Cross River, Akwa Ibom, Rivers, Bayelsa, Delta, Edo, Lagos, Ekiti, Ondo, Oyo, Kwara and Ogun.

${ }^{15}$ (2001) 43 NSCQR 118. 
nized Chieftaincy is validly made and registered, the native law and custom therein expressed shall be deemed to be the customary law regulating the selection of a person to be the holder of the recognized Chieftaincy to the exclusion of any other customary usage, rule or tradition. Such registered Declaration therefore becomes a declaration of the tradition, customary law and usages pertaining to the selection and appointment to the particular Chieftaincy throne or stool, which it relates.

In Olubodun v. Lawal' ${ }^{16}$, the Supreme Court was explicit that a major characteristic of customary law or custom was that it must be in existence at the relevant time and must be recognized and adhered to by the people to make it binding. And secondly, that it is a well established principle of law that documentary evidence is unknown to native law and custom. Section 18(1) of the Evidence Act provides that, where on the other hand, a custom cannot be established as one judicially noticed, it shall be proved as a fact. This position enjoys judicial support in Orlu v. GogoAbite ${ }^{17}$, where the Court stated that:

It is extremely important that custom should be strictly proved. Though such proof is not by the number of witnesses called, it is not enough that one who asserts the custom should be the only witness. Another witness who is versed in the alleged custom should also testify.

The Court went further to hold that native law and custom were matters of evidence to be decided on facts presented before the Court, unless it is of such notoriety and has been so frequently followed by the Courts that judicial notice would be taken of it without proof on evidence and that such evidence which is usually based on tradition has to be averred on pleadings and proved as being in line with the custom of a particular family or community. Similarly, in Olubodun v. Lawal ${ }^{8}$ the Court held that native law and custom not judicially noticed can be proved by evidence of witnesses belonging to the community to show that the people in that particular area regard the alleged customary law as binding on them.

There are numerous implications of these statutory provisions. Among them, no custom is law unless the Courts established through the instrumentality of the State declares it as such or, in the alternative, it is successfully proved as a fact. Barring these two conditions people can only allow custom to regulate their transactions at their peril. But there is even a bigger peril confronting customary law. Section 18(3) of the Evidence Act stipulates that in any judicial proceeding where any custom is relied upon, it shall not be enforced as law if it is contrary to public policy, or is not in accordance with natural justice, equity and good conscience. Whereas it is trite that the rules of natural justice are founded upon two pillars, namely, that all parties to a dispute must be heard and that no person shall be the judge in a case in which he is a party, what is equitable and of good conscience are imprecise and have no direct definition under the

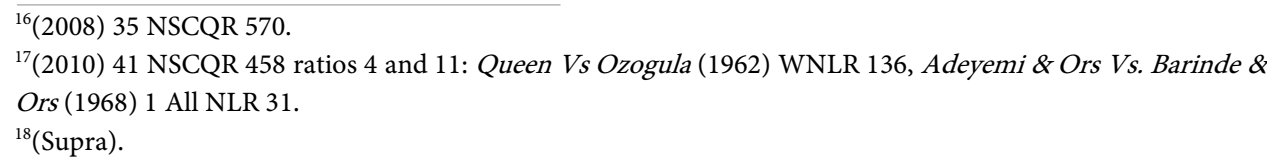


Nigerian legal system. In the circumstances, it is only the judge before whom such issue is raised that can determine, albeit most often arbitrarily, which facts or particular sets of circumstances were equitable or of good conscience. The statutes also add another formidable constraint, that is, for such customary law to be enforced it must not be incompatible with any written law in force within the jurisdiction of the Court applying the customary law. For instance, Section 12(i) (a) of the Ebonyi State Customary Courts Law provides that:

The customary law prevailing in the district or area of jurisdiction of the court is binding upon any of the parties so far as it is not repugnant to natural justice, equity and good conscience or incompatible either directly or by necessary implication with any written law for the time being in force in the State ${ }^{19}$.

This position has been upheld in a number of cases including Kopek vs. Ekisola ${ }^{20}$. But have the ends of justice been served in the end? This poser shall be resolved subsequently.

\subsection{Customary Law and Justice}

The picture of customary law in a traditional society is one in which the people are in harmony with the norms of their society. Norms that reward good conduct, punish abominations and misconduct and continuously guarantee stability in the society. This system for the administration of justice was in place and accessible to all that approached the temple of justice. In Igbo land this system was well regulated from the family level through the village level up to the clan or community level. There were two vertical paradigms for accessing justice. The one lane approximated what today is referred to in the Afikpo areas of Ebonyi State, Nigeria as the Ekpuke Eto, Ekpuke Essa and Nde Ichie Traditional Councils in ascending order whereas the other lane captured the family, village, community and clan levels in ascending order as well ${ }^{21}$. Every judgment presented an opportunity for appeal up to the peak of the lane chosen by the aggrieved party. But there was no rivalry between the two lanes for where a matter was tried for instance in the village or community assembly all the actors on the other lane where participants in the panel and vice versa. If there is any distinction, it is only in the area of age set or age grade for members of Ekpuke Eto up to Nde Ichie belonged to different classes of age grades whereas the village or community assembly accommodated all adults. Apart from the availability of the structure for adjudication, Nde Ichie the apex point of appeal were versed in the culture and tradition of the people and were forthright and spoke the truth in honour of, but above all for fear of, the gods and the

${ }^{19}$ Cap 47, Laws of Ebonyi State, 2009. Ebonyi is one of 36 States that make up Nigeria as Country with a Federal Capital in Abuja.

${ }^{20}(2010) 41$ NSCQR 553 ratio 9. See also the High Court Laws of Lagos and Ebonyi States.

${ }^{21}$ The Igbo is one of an estimated one hundred native tribes in Nigeria but one of the three largest ones, the other two being the Hausa and the Yoruba. The Ekpuke Eto; Ekpuke Essa, and Ndichie Traditional Councils each constitute a distinct Traditional Arbitral Panel. Ekpuke refers to Council and Eto refers to three. In the same token Ekpuke Essa is a native panel made of seven age grades where Essa refers to seven. Ndi Ichie refers to the Council of Elders. 
ancestors. These were the days that men gloried in truth and integrity and would never be identified with the subversion of the cause of justice for whatever reason(s). Both legal and social justice was administered concurrently and the society was the better for it.

But this picture has been blurred for the right and wrong reasons. From the colonial times, the value system of traditional African societies became increasingly invaded, adulterated and dislocated to the end that respect for wealth and the rich replaced the value for truth and honesty and the fear of the gods that invariably punished evil and abominable behaviour. Adherents of the new Christian religion knew that their God was forgiving and longsuffering and can forgive any offence unlike the gods of the traditional society who struck any offender instantly. That is why in the modern Courts people quickly and enthusiastically swear by the Bible knowing that it is a mere ceremony and then proceed to lie blatantly in their testimonies. Experience has shown that when such people chose to swear by the gun or machete they are overwhelmed by superstition and become more cautious about lying on oath. The corruption of the value system has direct impact on the dispensation of justice in contemporary times even under traditional as against statutory arrangements. People now think more of what they can gain in a particular circumstance than what society can gain by a fair dispensation of justice. Among the Ekpuke Eto, Ekpuke Essa and even in village assemblies there have arisen judgment syndicates who ply their trade for money's worth. When things do not work in harmony people become more fearful for themselves and of others. That is partly why in proceedings in these traditional assemblies quite a number of people do not want to voice the truth they know for fear of offending someone or group of people who have vested interest in the matter under trial.

Viewed differently, customary law was by no means a perfect one. There were elements of it that were crude, barbaric and unconscionable and they were enforced with the same vigour as the good aspects. We call to mind such issues as the killing of twins, Osu caste system and repressive widowhood practices. But modern customary law has been refined and whatever one may hold against the repugnancy test, and they are many, it takes the credit for such refinement ${ }^{22}$. Take for instance, the Osu caste system, such social segregation can make for neither legal nor social justice as we understand it today. It is encouraging therefore that both the Federal and the various State Governments have enacted statutes abolishing such practices in those jurisdictions where they hitherto obtained. Section 3 of the Abolition of the Osu System Law ${ }^{23}$ stipulates that:

Notwithstanding any custom or usage each and every person who on the date of the commencement of this law is $\mathrm{Osu}$ shall from and after such date cease to be $\mathrm{Osu}$ and shall be free and discharged from any consequences thereof, and the children thereafter to be born to any such person and the offspring of such person shall not be $O s u$, and the Osu system is hereby utterly forever abolished and declared unlawful.

\footnotetext{
${ }^{22}$ The repugnancy test has been examined in detail earlier in the work.

${ }^{23}$ Cap 3 Laws of Ebonyi State, 2009.
} 
Overlooking the presumptuousness of this law which we conceive to be a technical error, its overall impact and purport is indeed a welcome one. To drive the message home, Section $7(2)$ of the law bars any court from recognizing any custom or usage, which implies any disability on any person on the grounds of the Osu system. Similarly, Section 3 of the Abolition of Harmful Traditional Practices against Women and Children Law ${ }^{24}$ abolished and declared unlawful all customary traditional practices that were prejudicial to the legal rights and well being of women and children. Such practices were enumerated in Section 2 to include those of a scandalous or disgraceful nature which amounted to a failure to observe the fundamental rights of a woman or any child; allowed for a female genital mutilation or circumcision; were harmful to a widow including any practice which required the confiscation of her husband's property; child labour; or encouraged child abuse and neglect, and forced and early marriage of girls before the age of eighteen. Again, Section 7 bars any Court from recognizing any custom that encouraged these unjust practices. There are also laws which limit the minimum age of marriage to sixteen years ${ }^{25}$. The abolition of these negative customary practices has not only made customary law more humane but has enabled it to deliver both legal and social justice. And its overall impact on social development is indeed salutary.

To this end, these are a multiplicity of effects that customary law can have on social development. For one, it is the law that applies to a great majority of the Nigerian people and so its enhancement, or otherwise enforcement, will guarantee a smooth and progressive dispute resolution and social and individual transactions can become much more effective. Secondly, customary law is the law that governs and regulates almost all informal transactions in Nigeria such as marriage and inheritance issues as well as land tenure in rural societies. As such, its refinement and enforcement would definitely achieve some social stability and progress. Thirdly, most of the vices that inherent under the received English adjudicatory process such as prolonged delays in litigation, corruption resulting in flawed judgments and high cost of litigation are minimized or nearly absent under the customary system of adjudication. There is a general perception that the customary adjudicatory system is more trustworthy and reliable than the received English system and people are much more willing to imbibe it.

Notwithstanding the forgoing, there is need to employ more practical approaches to the implementation of customary law. The validity tests earlier discussed are good to eliminate retrogressive, archaic and even primitive or otherwise unconscionable aspects of the law. But hanging the fate of customary law on the validity tests alone is unproductive and cannot achieve the desired social progress urgently needed in the country's legal system. It is therefore urged that deliberate and concerted steps be taken along the path of restatement, codification and unification of customary laws in Nigeria. A restatement of customary laws would have them produced in a text or document and can achieve a number of purposes ${ }^{26}$. If the restatement is produced under the authority of ${ }^{24}$ Cap 2 Laws of Ebonyi State, 2009.

${ }^{25}$ See for instance the Age of Marriage Law, CAP 9 Laws of Ebonyi State, 2009.

${ }^{26} \mathrm{By}$ Restatement we mean the collection and systematic arrangement of customary laws. 
Government, it becomes part of, and may be cited as, a public document under Section 102(a) of the Evidence of $\mathrm{Act}^{27}$. If it becomes a public document, it is easier to attract judicial notice by the courts under Section 16(1) of the Evidence Act. However, this judicial notice can only be consummated when the custom has been adjudicated upon once by a superior court of record ${ }^{28}$. Again, codification would make customary law much more effective and enforceable since they would have been enacted by the legislature into statutory law. However, it is necessary to regularly amend the codified law to reflect the progressive changes and social and legal realities that continuously occur not only in the society but with the customs of the people. Another practical step to achieve social development through customary law is by unification. A unified customary law would definitely answer to the needs of an industrialized, socially mobile, and progressively enlightened and educated society, which is the ultimate destination of the Nigerian society. Customary arbitration exemplifies some of the areas in which unification can prove to serve some practical purpose.

\subsection{Customary Law and Arbitration}

This does not envisage arbitration under the statutes or one powered by the statutes ${ }^{29}$. Customary arbitration is an informal arrangement generated from and by the customs and practices of the people from time immemorial whereby people submitted their disputes to the family, village, community, clan or other classes of authority for settlement. According to Kolajo (2001):

Customary arbitration is a common method of settling disputes in all indigenous

Nigerian societies. Costmary law arbitration is arbitration of dispute founded on the voluntary submission of the parties to the decision of the arbitrators who are either chiefs or elders of their community. (Kolajo, 2001)

By a long line of judicial authorities, customary arbitration is valid and enforceable in Nigeria if it meets the threshold for validity set by the Courts ${ }^{30}$. In Okoye v. Obiaso ${ }^{31}$, one of the recondite issues which the Supreme Court determined was whether customary arbitration pleaded by both parties was proved and, if so, what was the legal consequence of such proof. In resolving the issue the Court held that a party can prove the existence of a customary arbitration by pleading and establishing that there was a voluntary submission of the matter in dispute to an arbitration of one or more persons; that it was agreed by the parties either expressly or by implication that the decision of the arbitrators will be accepted as final and binding; that the said arbitration was in ac-

\footnotetext{
${ }^{27}$ Cap. E14 Laws of the Federation of Nigeria, 2010.

${ }^{28}$ Section 17 of the Evidence Act, Cap. E14 Laws of the Federation of Nigeria, 2010.

${ }^{29}$ See for instance the Arbitration Law Cap 14 Laws of Ebonyi State, 2009; the Arbitration Law of Lagos State, and the Arbitration Act applicable throughout the Federation of Nigeria.

${ }^{30}$ See Njoku v Ekeocha \& Anor (1972) 2 ECSLR 199; Mgbagbu v. Agochukwu (1993) 3 ECSLR (Pt.1) 90; Ofomata v Anoka (1974) 4 ECSLR 251; Ojibah v Ojibah (1991) 22 NSCC (Pt.2) 130; Ohiaeri v. Akabeze (1992) 23 NCC (Pt.1) 139; Nkado v. Obiano (1993) 4 NWLR 6; Igbokwe v. Nlemchi (1996) 2 NWLR (Pt.429) 185.

${ }^{31}$ (2010) 41 NSCQR 955.
} 
cordance with the custom of the parties or of their trade or business; that the arbitrators reached a decision and published their award; and that the decision or award was accepted at the time it was made. When these conditions are fully met, according to the Court, such arbitral judgment or ruling is as binding as the judgment of any Court. It is instructive to observe here that by necessary implication where such arbitral ruling no matter how unanimously made falls short of any of the requirements, it is invalid and of no legal effect. And further that these requirements are a safeguard against manipulated arbitral judgments, for it is common knowledge that sometimes judgments are won in village, community or traditional councils not on the merits but on the wings of power peddlers and influential actors supporting the cause of the victorious party. A unified and codified customary law on arbitration could enhance certainty and transparency in arbitral proceedings.

\section{Conclusion}

This work has ex-rayed the essence, merits and shortcomings of customary law. It has shown, by adducing statutory and judicial authorities, its legal status in the contemporary Nigerian justice system; among them, that customary law is no law except it can pass the repugnancy tests set for it by the statutes. The ideal customary law operating in the traditional society has been evaluated alongside the content and validity of customary arbitration. The paper has equally made out a case for the restatement, codification and unification of customary laws. Above all, the work has highlighted the capacity of customary law to evoke both legal and social justice and its potentials for social development and the administration of justice in Nigeria. It is expected that the work will be useful particularly to the legislature and the judiciary, which ought to be keen on the legal but most importantly on the social content of justice delivery.

\section{References}

Age of Marriage Law, CAP 9 Laws of Ebonyi State, 2009.

Arbitration Act, Laws of the Federation of Nigeria, 2010.

Arbitration Law of Lagos State, 2003.

Ebonyi State Customary Court Law CAP. 47 Laws of Ebonyi State, 2009.

Evidence Act, CAP. E14 Laws of the Federation of Nigeria, 2010.

Garner, B. A. Ed. (2009). Black’s Law Dictionary(9th.ed.). Minesota: West Publishing Co.

Holmes, W. (2013). The Path of the Law. In M. E. Nwocha, Ed., Human Rights and Criminal Justice in Nigeria. Abakaliki: CE Darrolls Publishers.

Ibrahim, H. (2012). Practicing Sharia Law. Illinois: ABA Publishing.

Kolajo, A. A. (2001). Customary Law in Nigeria through the Cases. Ibadan: Spectrum Books Ltd.

Obilade, A. O. (1979). The Nigerian Legal System. Ibadan: Spectrum Books Ltd.

Trost, J. et al. (2005). Hardbook on World Families. London: Sage Publications.

Umoh, P. U. (2013). Law in African Context. In M. E. Nwocha, Ed., Human Rights and Criminal Justice in Nigeria. Abakaliki: CE Darrolls Publishers. 
Submit or recommend next manuscript to SCIRP and we will provide best service for you:

Accepting pre-submission inquiries through Email, Facebook, LinkedIn, Twitter, etc. A wide selection of journals (inclusive of 9 subjects, more than 200 journals)

Providing 24-hour high-quality service

User-friendly online submission system

Fair and swift peer-review system

Efficient typesetting and proofreading procedure

Display of the result of downloads and visits, as well as the number of cited articles

Maximum dissemination of your research work

Submit your manuscript at: http://papersubmission.scirp.org/

Or contact blr@scirp.org 